\title{
ACKNOWLEDGMENTS
}

This book is not the book I thought it would be ten years ago when I started the standard-setting process at the ILO. I acknowledge the many colleagues who welcomed and nourished my commitment to this topic from the start of my affiliation with the ILO in 1993-in particular, Anne Trebilcock, Shauna Olney, Zafar Shaheed, Edward Yemin, and Mary Hamouda. I thank Manuela Tomei for immediately recognizing the significance of the standard-setting process in 2008, and entrusting me with the drafting of the ILO's Law and Practice Report ("Report IV(1)"). I also thank Cleo Doumbia-Henry, who tutored me in the standard-setting process as soon as I was appointed. It was an honor to work with the many international labor officials who contributed in a myriad of important ways to the success of the ILO standard-setting process. Throughout the process, I interacted with representatives of a number of other international organizations and independent experts of the Office of the United Nations High Commissioner for Human Rights, including those affiliated with the Women in Informal Employment: Globalizing and Organizing (WIEGO) network and Human Rights Watch, who contributed significantly to the overall process.

I thank the Fondation du Barreau du Québec, which not only provided startup funding for me to pursue comparative law research on citizenship at work for domestic workers, focusing on collective bargaining and compliance simplification mechanisms such as service checks in France, but also generously agreed that my own publications on this topic would be deferred so that I could contribute both time and the fruit of that research to the ILO in support of the standard-setting process.

Gregor Murray, director of the Interuniversity Research Centre on Globalization and Work (CRIMT), and his colleagues supported the International Seminar on Decent Work for Domestic Workers, funded by the Government of Canada as part of the International and Comparative Dialogue Celebrating the ILO at 90 and Preparing for Standard-Setting into the Future, on March 29, 2010. Selected papers presented at the conference 
were published in a special issue of the Canadian Journal of Women and the Law in 2011.

I was grateful for the precious research time afforded by the Social Science and Humanities Research Council's 2010 Bora Laskin National Fellowship in Human Rights Research, which enabled me to think through the relationship between human rights, legal pluralism, and relative power. The International Development Research Centre provided a small grant for research innovation, which enabled me to meet with social and institutional actors in South Africa, Côte d'Ivoire, and Kenya. Support to finalize the book has come from my appointment as Canada Research Chair in Transnational Labour Law and Development. In each of these contexts I worked with teams of researchers, and I wish to thank especially Evance Kalula from the University of Cape Town, Fairuz Mullagee and Darcy du Toit from the University of Western Cape, Assata Koné-Silué from Université Houphouët Boigny in Côte d'Ivoire, Lyn Ossome from the Makerere Institute of Social Research, and Dzodzi Tsikata from the University of Ghana in Legon. Interviewees in Côte d'Ivoire, France, Kenya, South Africa, and Switzerland were extremely generous with their time and insights. I am grateful to them all.

Many colleagues invited me to present portions of this work while it was in progress and offered comments or encouragement along the way. They include Gay McDougall (Office of the High Commissioner for Human Rights' Forum on Minority Issues, 2010); Judy Fudge, Shae McCrystal, and Kamala Sankaran (Oñati Institute for the Sociology of Law, 2010); Kim Rubenstein (University of Canberra, 2011); Ron McCallum (University of Sydney, 2011); John Howe (University of Melbourne, 2011); Evelyn Calugay and Fo Niemi (Filipino Women's Organization in Quebec, PINAY, and the Center for Research-Action on Race Relations, 2012); Valerie Oosterveld (Canadian Council on International Law, 2012); Chrysal Kenoukon (Université D’Abomey Calavi, 2013); Katherine Lahey and Bita Amani (Queen's University, Ontario, 2014); Julia López and Chelo Chacartegui (Pompeu Fabra University, 2014); Evance Kalula and Rochelle LeRoux (University of Cape Town, 2014); Darcy DuToit and Fairuz Mullagee (University of Western Cape, 2015); Peggie Smith and Angela Onwuachi-Willig (Lutie Lytle Workshop at Vanderbilt University, 2015); Elsa Gallerand and Martin Gallié (Université du Québec à Montréal, 2015); Kerry Rittich and Jennifer Nedelsky (University of Toronto, 2015); Pierre-Paul Van Gehuchten, Pascale Vielle, Marthe Nyssens, and Olivier de Schutter (Université de Louvain, 2015); Claire Thompson (International Development Research Centre, 2016); Lorena Poblete (Princeton University, 2016); Diamond Ashiagbor (University of London, 2016); and Marty Chen and WIEGO (Harvard University, 2017). Many other colleagues offered detailed 
comments on my work. They include Harry Arthurs, Eileen Boris, Michael Fischl, Guy Mundlak, Jim Pope, Peggie Smith, Anne Trebilcock, and Lea VanderVelde. The Labour Law Research Network and the annual meetings of the Law and Society Association have been prime sites for critical feedback throughout the writing of this book and encouragement to stick with the project. This book is stronger because I had these occasions to interact and exchange ideas with colleagues.

I am also grateful to my deans at the Faculty of Law at McGill University, who accommodated me in my role of providing academic expertise to the ILO on standard setting for decent work for domestic workers and my research for this book. My sabbatical in 2014-15 was a decisive time that enabled me to consolidate much of my writing, but it was the support of the Canada Research Chair in Transnational Labour Law and Development that made completion possible. Writing retreats at the Monastère des Augustines in Quebec City provided the space and calm necessary to bring this book to fruition. At McGill I also thank Catherine LeGrand, Colleen Sheppard, François Crépeau, Vrinda Narain, Alana Klein, and Tina Piper for their support.

I worked with tremendous teams of undergraduate and graduate student research assistants over the decade that this book was in progress, as well as during the standard setting. I live in fear of forgetting someone, as they were all formidable. Several are mentioned throughout this book and in other related publications. In alphabetical order, they include Michael Blashko, Amina Chaouni, Maude Choko, Sarah Goldbaum, Tatiana Gómez, Renz Grospe, Alika Hendricks, Katie Kaufman, Aurélie Lanctôt, Sydney Lang, Alice Mirlesse, Mae Nam, Marion Rebière, Marie-Alice Remarais, Cassandra Richards, and Marion Sandilands.

Fran Benson of the ILR Press imprint of Cornell University Press was an early believer in this book. Her support kept me focused not only on completing the book, but also on keeping it accessible. This book has also benefited from the editorial skills and insights of Erin Davis and the team at Westchester Publishing, as well as McGill law student Talia Ralph, who as a food industry journalist shares my passion for cookbooks.

I owe a debt of gratitude to my partner, Aristide Nononsi, and children, Jean-Richard and Baï Daisy, who have also spent a decade living with this book. Baï Daisy would sit beside me as I was drafting it, and draw pictures like the one reproduced below (figure 1). My family have all been gracious about it and have been making some of those recipes I have been writing about.

Finally, I am grateful to Evelyn Mondonedo Calugay and the committed community supporting domestic workers at PINAY in Montreal; Myrtle 


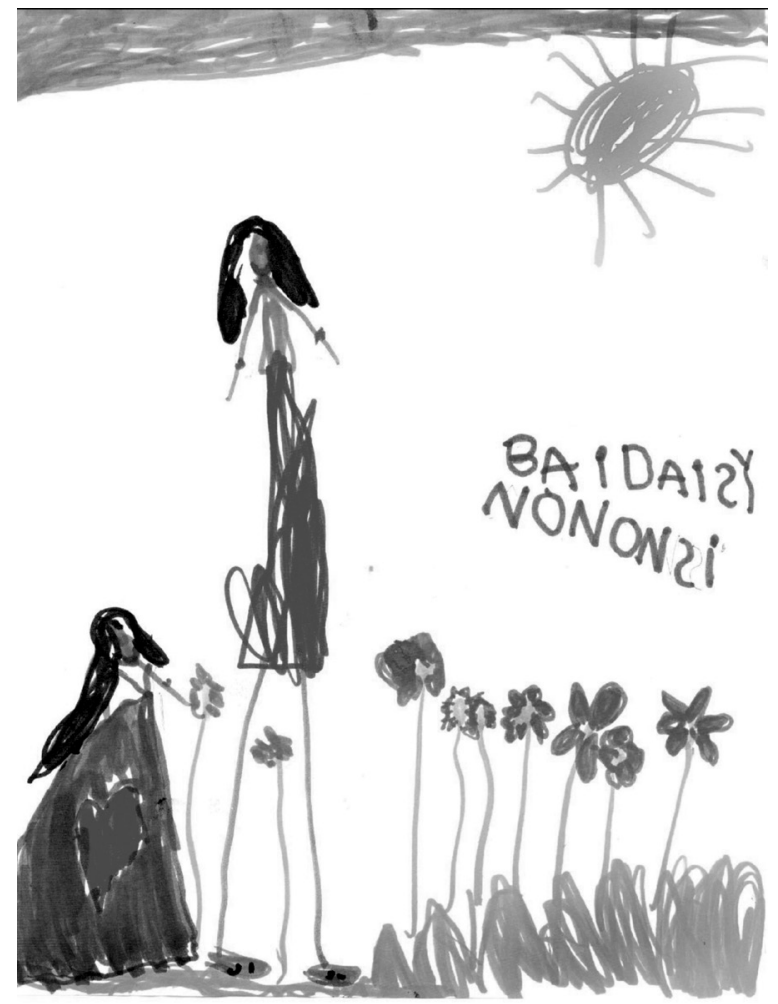

FIgURE 1. Portrait of the artist and her mother. Credit: Baï Daisy Nononsi.

Witbooi and the movement of domestic workers at the International Domestic Workers' Federation; and, of course, Muriel Blackett and Lucien Smith. Their courage and conviction on social justice for domestic workers sustains this work.

Montreal, January 5, 2018 


\section{EVERYDAY TRANSGRESSIONS}


